dr Bożena Majerek

Uniwersytet Papieski

Jana Pawła II w Krakowie

s. Milena Frączek

Zgromadzenie Sióstr Albertynek

Posługujacym Ubogim
Eliminacja wykluczenia społecznego, red. M. Duda, K. Kutek-Sładek, Kraków 2017, s. 55-63 (Praca Socjalna w Teorii i Działaniu, 3).

DOI: http://dx.doi.org/10.15633/9788374385824.05

\title{
Proces wychodzenia z bezdomności kobiet uzależnionych od alkoholu
}

\author{
The process of overcoming homelessness \\ of women addicted to alcohol
}

\begin{abstract}
This article presents the results of qualitative research on the process of getting out of homelessness women addicted to alcohol. In order to identify protective factors and risk analyzes the circumstances examined with a special focus on aspects of family, economic and professional. Alcohol was considered a major problem in the process of getting out of homelessness respondents therefore also analyzed its role and importance in the lives of women surveyed.
\end{abstract}

It was found, however, that he was the only one available for the tested way of dealing with virtually every problem. Therefore, designing appropriate measures of preventive and therapeutic, consider the whole spectrum of medical problems, which in many wind up homeless, difficult to stop the vicious circle of life's setbacks and tragedies.

Keywords: pathology, homelessness, alcoholism

Bezdomność jest złożonym i wielowymiarowym zjawiskiem społecznym. Podejmowana w obrębie tego zagadnienia analiza wymaga bowiem uwzględnienia również innych problemów, które bardzo często dookreślają sytuację człowieka pozbawionego domu, tj. alkoholizmu, narkomanii, prostytucji czy przestępczości. Czynniki te w zależności od indywidualnej sytuacji życiowej mogą być albo przyczyną, albo skutkiem bezdomności. Podejmując zatem działania profilaktyczne i terapeutyczne na rzecz osób bezdomnych, należy uwzględnić fakt, iż zazwyczaj ważniejsze od aspektów ekonomiczno-materialnych są niekorzystne 
czynniki psychologiczne charakteryzujące takie osoby (np. niski poziom własnej wartości, brak poczucia godności i szacunku, niski poziom poczucia sprawstwa, bierność, brak poczucia przynależności i tożsamości społecznej). Niewątpliwie bardzo ważne są inicjatywy i programy, które uwzględniają rzeczywistą sytuację i realne potrzeby beneficjentów. Takie szerokie spojrzenie wymaga jednak niewątpliwie interdyscyplinarnych badań i działań praktycznych.

\section{Założenia teoretyczne}

Proces wychodzenia $\mathrm{z}$ bezdomności to wieloetapowe, niezwykle skomplikowane i obarczone wieloma problemami zjawisko społeczne. Wymaga wielu starań i wysiłku ze strony zarówno bezdomnych, jak i osób im pomagających. Niestety jednak pomimo dobrego przygotowania, ogromnego zaangażowania i pozytywnej motywacji zainteresowanych rezultat nie zawsze jest zbieżny z zamierzeniami i początkowymi postanowieniami.

Pierwsze wzmianki na temat zjawiska bezdomności w Polsce pochodzą z okresu średniowiecza, wtedy bezdomnych nazywano luźnymi ludźmi. Początkowo termin „bezdomny” kojarzono jedynie z ofiarami wojen i powstań, z czasem dopiero przeszedł do języka prawniczego i określał osoby, które także z różnych innych powodów utraciły stałe miejsce zamieszkania ${ }^{1}$. W spółcześnie, pomimo znacznego badawczego i społecznego zainteresowania tą problematyką, nadal brak spójnych koncepcji, teorii czy chociażby definicji podstawowych terminów. Zgodnie z treścią art. 6 pkt. 8 z Ustawy z dnia 12 marca 2004 r. o pomocy społecznej bezdomny to „osoba niezamieszkująca w lokalu mieszkalnym w rozumieniu przepisów o ochronie praw lokatorów i mieszkaniowym zasobie gminy i niezameldowana na pobyt stały, w rozumieniu przepisów o ewidencji ludności i dowodach osobistych, a także osoba niezamieszkująca w lokalu mieszkalnym i zameldowana na pobyt stały w lokalu, w którym nie ma możliwości zamieszkania"2.

Warto również podkreślić fakt, iż także w opracowaniach międzynarodowych brak jednoznacznych określeń. Często jednak w różnych analizach badacze odwołują się do prac prowadzonych przez Europejską Federację Narodowych Organizacji Pozarządowych Pracujących na Rzecz Bezdomnych (FEANTSA), która opracowała typologię bezdomności i wykluczenia społecznego ETHOS. Typologia ta oparta jest na pojęciu „dom”, które tworzy trzy domeny: fizyczną

\footnotetext{
B. Baranowski, Ludzie gościńca w XVII-XVIII w., Łódź 1996.

Ustawa z dnia 12 marca 2004 r., o pomocy społecznej, Dz.U. nr 64, poz. 593, art. 6, pkt. 8 .
} 
(chroniąca przed złymi warunkami atmosferycznymi), społeczną (chroniąca i gwarantująca prywatność, dająca przestrzeń do czerpania satysfakcji z relacji społecznych) i prawną (tytuł prawny do danego schronienia). Według Federacji brak chociaż jednej z domen oznacza bezdomność ${ }^{3}$.

Wielowymiarowość zjawiska bezdomności wynika przede wszystkim z faktu, iż jest ono wieloetapowe i przybiera postać postępującego procesu. Marek Jaździkowski wymienia pięć kolejnych faz rozwoju syndromu bezdomności:

1. Faza wstępna - trwa około dwóch lat od momentu pozostania bez stałego miejsca zamieszkania. Osoba będąca w tej fazie utrzymuje sporadyczne i stale słabnące kontakty z rodziną. Aby nie przeżywać negatywnych odczuć, zaprzecza swojej bezdomności. Często zaczyna pojawiać się problem $\mathrm{z}$ nadużywaniem alkoholu.

2. Faza ostrzegawcza - trwa na ogół kolejne dwa lata. Następuje dalsze osłabienie więzi rodzinnych i wzrost identyfikacji ze środowiskiem bezdomnych alkoholików.

3. Faza adaptacyjna to kolejne dwa lata, w czasie których osoba bezdomna jest już zazwyczaj po kilku próbach wyjścia z tego stanu. Etap ten łączy się ze świadomą i emocjonalną akceptacją utraty domu i poczucia upadku, a także z przystosowaniem się do ubóstwa i braku planów życiowych.

4. Faza chroniczna, którą datuje się na kolejne cztery lata, polega na pełnym przystosowaniu się do warunków bezdomności (zerwanie kontaktów $\mathrm{z}$ rodziną, czasowe pomieszkiwanie w schronisku). Często jednak z powodu braku higieny i pogłębiania się alkoholizmu znacznie pogarsza się stan zdrowia osoby bezdomnej, następuje również rezygnacja i brak dostrzegania perspektyw i wartości w życiu.

5. Faza bezdomności trwałej to okres trwający dłużej niż 10 lat. Na tym etapie bardzo trudne jest samodzielne funkcjonowanie w społeczeństwie; osoba bezdomna wypala się i nabywa osobowość bezdomnego ${ }^{4}$.

Należy zaznaczyć, iż według badaczy na każdym z wymienionych etapów możliwe jest wyjście z bezdomności, jednak upływający czas i zmiany, jakie zachodzą w osobie bezdomnej, mogą ten proces utrudnić.

Fazy przechodzenia w stan bezdomności uwarunkowane są przez wiele czynników, które również należy uwzględnić, projektując działania wspierające bezdomnego w procesie wychodzenia z tego stanu. Najogólniej można

3 E. Jaroszewska, Bezdomni jako zbiorowość wykluczona społecznie, [w:] Ubóstwo i wykluczenie społeczne-perspektywa poznawcza, red. R. Szarfenberg, C. Żołędowski, M. Teiss, Warszawa 2010, s. 278-279.

4 M. Jaździkowski, Syndrom bezdomności, http://www.bratalbert.org/files/brat_albert/pdf/marek_jazdzikowski_syndrom_bezdomnosci.pdf (dostęp: 15.04.2014). 
powiedzieć, że bezdomność może być wynikiem sytuacji społeczno-ekonomicznej kraju (np. wzrost bezrobocia, brak miejsc w szpitalach czy zakładach opiekuńczych, domach pomocy społecznej), sytuacji prawnej (np. zaległości w opłatach czynszowych, eksmisja), patologii (np. alkoholizm, narkomania, przestępczość), czynników socjopsychologicznych (np. odrzucenie obowiązującego systemu wartości, świadomy wybór innego sposobu życia), czynników osobowościowych (np. zaburzenia psychiczne, poczucie osamotnienia, wstyd). Niewątpliwie wskazać należy na przyczyny pojawiające się po stronie samych bezdomnych, tj. zakłócony proces socjalizacji w grupach pierwotnych (np. brak przygotowania do samodzielnego życia i mieszkania), nieumiejętność przystosowania się do sytuacji społeczno-ekonomicznej (np. brak możliwości zatrudnienia za godziwą płacę), nieprzystosowanie do sytuacji obyczajowo-kulturowej ${ }^{5}$.

W wielu opracowaniach podkreśla się fakt różnorodności i złożoności przyczyn bezdomności. Niewątpliwie jednak jednym z głównych i najczęściej pojawiających się czynników jest alkohol. Pomoc w wychodzeniu z bezdomności osobom, które dodatkowo zmagają się z alkoholizmem, wymaga uwzględnienia nie tylko braków materialnych (mieszkanie, praca), ale głównie problemów psychicznych i społecznych. Terapia odwykowa osób bezdomnych nie jest łatwym zadaniem $\mathrm{z}$ wielu powodów - najważniejszym z nich jest negatywny stosunek samych badanych do leczenia. Jak zaznacza Bogdan Woronowicz, główną przyczyną takiego stanu rzeczy jest przede wszystkim brak identyfikacji alkoholików z chorobą, wzmacniany izolacją społeczną związaną z przebywaniem w środowisku osób z podobnymi problemami, negatywne doświadczenia z placówkami ochrony zdrowia czy złe doświadczenia z esperalem i udziałem w programach terapeutycznych ${ }^{6}$.

Pomoc w wychodzeniu z bezdomności stawia zatem wiele wymagań zarówno osobom bezdomnym, jak i instytucjom oraz jednostkom udzielającym pomocy. Obecnie istnieje wiele instytucji oraz nowych inicjatyw społecznych, dzięki którym osoby potrzebujące mogą uzyskać odpowiednią pomoc np.: noclegownie, hostele, przytuliska, domy aktywności życiowej, domy samotnej matki, jadłodajnie, łaźnie, domy dziennego pobytu. Pomimo, wydawałoby się dość rozbudowanego i sprawnie funkcjonującego systemu pomocy świadczonego na rzecz osób bezdomnych, zdaniem Andrzeja Przymeńskiego należy wskazać na wiele jego wad np. charytatywny oraz uznaniowy model udzielania pomocy, wadliwa rejonizacja, niesprawiedliwy poziom traktowania bezdomnych, brak

5 E. Moczuk, Bezdomność jako problem społeczny w opiniach osób bezdomnych, [w:] Poczucie nieegalitarności, ubóstwo, bezdomność a zjawiska patologii społecznej waktualnej rzeczywistości kraju, red. T. Sołtysiak, Włocławek 1999, s. 231-246.

6 B. T. Woronowicz, Bez tajemnic o uzależnieniach i ich leczeniu, Warszawa 2001. 
obowiązujących standardów minimalnej pomocy udzielanej bezdomnym ${ }^{7}$. Wydaje się również, iż istotną przyczyną podejmowania nie zawsze optymalnych działań jest niewystarczająca ilość realizowanych w tym obszarze badań naukowych, a co za tym idzie niewielka liczba opracowań problemowych. Niebagatelny problemem dostrzec można już chociażby na poziomie ustalania rzeczywistej liczby osób bezdomnych. Wydaje się zatem oczywiste, że intensyfikacja dobrze zaprojektowanych badań podniesie poziom skuteczności proponowanych działań pomocowych.

\section{Podstawy metodologiczne}

Bezdomność jest na ogół konsekwencją licznych niepowodzeń, kryzysów, konfliktów, utraconych możliwości i chorób. Jednak jest ona przede wszystkim osobistym nieszczęściem i tragedią konkretnych ludzi, którzy nie zawsze z własnej winy znaleźli się w tak trudnej sytuacji życiowej. Omawiany problem coraz częściej staje się również udziałem kobiet, które nadużywając alkoholu, szybciej niż mężczyźni doznają dojmujących szkód somatycznych i psychicznych.

Głównym celem przeprowadzonych badań były analiza i opis procesu wychodzenia $\mathrm{z}$ bezdomności kobiet uzależnionych od alkoholu. Do problemu głównego sformułowano trzy kolejne problemy szczegółowe:

1. Jaka jest sytuacja życiowa badanych kobiet?

2. Jakie ma znaczenie alkohol w życiu badanych kobiet?

3. Jak badane kobiety radzą sobie z problemami życiowymi?

Aby zrealizować zamierzenie badawcze, zastosowano pogłębiony wywiad, który składał się z 60 otwartych pytań odpowiednio dobranych do sytuacji badanych osób.

Badania przeprowadzono z czterema osobami, zamieszkującymi czasowo w jednym z przytulisk dla bezdomnych kobiet w Krakowie.

\section{Analiza wyników badań}

Zjawisko wychodzenia z bezdomności osób uzależnionych od alkoholu jest niezwykle trudnym i złożonym problemem, który ze względu na pojawiające się traumatyczne przeżycia wymaga nie tylko bardzo starannego przygotowania

7. Przymeński, Aktualny stan problemu bezdomności w Polsce. Aspekt polityczno-społeczny, [w:] Oblicza bezdomności. Materiały pokonferencjyjne, red. M. Dębski, K. Stachura, Gdańsk 2007. 
merytorycznego i metodologicznego, ale również wyjątkowej wrażliwości badawczej. Zgodnie ze sformułowanymi problemami szczegółowymi poniżej przedstawiono sytuację życiową badanych kobiet, zwracając szczególną uwagę na wyodrębnienie czynników chroniących i ryzyka dla procesu wychodzenia z bezdomności. Drugi obszar analizy związany był z chorobą alkoholową badanych, a ostatni dotyczył wyznaczenia sposobów radzenia sobie z problemami życiowymi przez badane kobiety.

Poddając analizie sytuację badanych kobiet, uwagę koncentrowano szczególnie na ich sytuacji rodzinnej oraz zawodowo-finansowej. Na podstawie uzyskanych informacji stwierdzono, że aż trzy spośród badanych pochodziły z patologicznych środowisk, dotkniętych przede wszystkim alkoholizmem i przemocą. Jedna z badanych tak opisała swoje dzieciństwo: „Czułam się niechciana. W rodzinie zastępczej byłam bita patelnią, przypalana, spałam na balkonie. Wagary, ucieczki. Ojczym bawił się mną. Uciekałam do Kościoła. Wszyscy widzieli, tylko nikt nie reagował". Dramatyczna sytuacja życiowa badanych oraz wstyd i zażenowanie z powodu własnego alkoholizmu i bezdomności sprawiły, że obecnie kobiety bardzo rzadko utrzymują jakiekolwiek kontakty z członkami rodziny. Jak same twierdzą, relacje $\mathrm{z}$ najbliższymi i tak nie były zbyt dobre, a od kiedy badane stały się bezdomnymi, prawie zanikły. Jedynie dwie osoby deklarują, że bardzo chciałyby odbudować te zerwane więzi z najbliższymi, co niewątpliwie może stanowić istotny czynnik wzmacniający w procesie wychodzenia z uzależnienia i bezdomności. Pozostałe natomiast nie chcą, a nawet nie widzą możliwości powrotu do dawnych, patologicznych środowisk. Niemniej jednak wszystkie kobiety zdają sobie sprawę z faktu, iż muszą od nowa uczyć się nawiązywania i podtrzymywania pozytywnych relacji z innymi ludźmi.

Jednym z najczęstszych powodów bezdomności są oczywiście problemy ekonomiczne. Również sytuacja finansowa badanych kobiet jest dość trudna, co może stanowić istotny czynnik ryzyka w wychodzeniu z bezdomności. Tylko jedna spośród badanych kobiet ma pracę, reszta natomiast utrzymuje się z bardzo niskich zasiłków zdrowotnych, przyznanych ze względu na orzeczony stopień niepełnosprawności. Za otrzymywane kwoty badane niestety nie będą w stanie się usamodzielnić. Ten fakt może generować efekt błędnego koła, bowiem brak stałej pracy oraz zależność finansowa łączą się nierozerwalnie z poczuciem bezsensu, bezradnością i w końcu rezygnacją z podjętych starań. Tym bardziej że, jak mówią badane, wielu potencjalnych pracodawców odnosiło się do nich nieufnie, mimo że żaden z paragrafów obecnie obowiązującego kodeksu pracy nie zabrania zatrudnienia osoby bezdomnej. Należy również podkreślić fakt, iż badane kobiety mają zarówno odpowiednie wykształcenie (wyższe, średnie techniczne i zawodowe), jak i staż pracy (od 6 do 30 lat), zatem należy przypuszczać, że przy odpowiedniej pomocy w znalezieniu zatrudnienia badane mają 
szansę zaistnieć na rynku pracy. Ten fakt należy uznać za czynnik wspierający $\mathrm{w}$ procesie ponownej socjalizacji badanych.

Z przeprowadzonych rozmów wynika, że alkohol prawie zawsze miał istotne znaczenie w życiu badanych. Towarzyszył ich dzieciństwu i dorastaniu, stając się dla większości jedynym dostępnym sposobem nie tylko radzenia sobie w sytuacjach trudnych, ale też funkcjonowania w codzienności. Jedna $\mathrm{z}$ badanych mówi „piłam na imprezach, wyjazdach ze znajomymi, dyskotekach, wagarach szkolnych, na meczach wyjazdowych, żeby poznać chłopaka. Każda okazja była dobra. Kiedy odzywały się wspomnienia związane z mamą, jak brakowało mi zrozumienia i akceptacji ze strony rówieśników (stawałam się odważna), nie umiałam odnaleźć się w życiu”.

Przełomowym momentem dla każdej uzależnionej osoby jest identyfikacja występującego problemu. Badane w różnych momentach swojego życia dostrzegły, że mają problem alkoholowy. Dla jednej z nich był to moment, kiedy uzmysłowiła sobie, że pierwszą myślą każdego poranka był alkohol, dla drugiej atak epilepsji. Trzecia spośród kobiet zobaczyła problem, dopiero gdy odebrano jej dziecko i gdy trafiła do przytuliska, natomiast kolejna po lekturze książki na temat uzależnień, identyfikując na jej podstawie wiele własnych przyzwyczajeń i symptomów.

Czas trwania w chorobie alkoholowej wśród badanych waha się od 4 do 27 lat jak twierdzą obecnie, alkohol nie tylko nie rozwiązał ich ówczesnych problemów, ale spowodował kolejne. Przez alkohol kobiety utraciły „dom, zaufanie, bliskie osoby, godność i to, co chciałam w życiu osiągnąć”. Inna dodaje: „straciłam syna, chłopaka, pracę, rodzinę, siebie, godność, szacunek, wiarę, kontakty, relacje, więzi, miłość, ciepło i wrażliwość". Należy zatem uznać, że uświadomienie sobie konsekwencji choroby alkoholowej może stanowić pozytywny moment w procesie terapii alkoholowej. Niestety skutki alkoholizmu są jednak często tak dalekosiężne, że uświadomienie sobie straty części własnego życia i rodziny może jednak także sprzyjać nawrotom choroby.

Warto podkreślić fakt, iż żadna z badanych kobiet nigdy nie przypuszczała, że kiedykolwiek stanie się osobą bezdomną, dlatego też decyzja o podjęciu leczenia była dla nich bardzo trudna. Badane podkreślają fakt, iż czasowa abstynencja, podejmowana ze względu na pracę, rodzinę czy własne zdrowie, dawała czasową iluzję panowania nad problemem. Niestety dla badanych zarówno alkoholizm, jak i bezdomność stały się faktem i jak ustalono, okres bezdomności połączonej z alkoholizmem waha się od 3 do 9 lat. W trakcie tego czasu badane wielokrotnie już podejmowały próby wyjścia $\mathrm{z}$ bezdomności. Jedna $\mathrm{z}$ nich wróciła do Przytuliska po ośmiu latach samodzielnego życia. Inne mówią, że to ich siódma lub ósma próba. Obecnie badane pozytywnie oceniają to kolejne podejście i wolę wyzdrowienia. Jedna z nich mówi: „jestem na dobrej drodze, 
ale jeszcze nie jestem na tyle silna, żeby opuścić przytulisko i usamodzielnić się", inna natomiast dodaje: „tutaj czuję się bezpiecznie. Teoretycznie mogłabym wynajmować mieszkanie, ale boję się, że wrócę do picia. Nie opanowałam sytuacji związanych z piciem". Badane kobiety dostrzegają pozytywne zmiany, które pojawiły się wraz z abstynencją i terapią, czego potwierdzeniem są słowa jednej z mieszkanek Przytuliska: „zaczęłam się szanować, odzyskałam godność jako osoba i kobieta. Czuję się akceptowana i szanowana. Odzyskałam wrażliwość, umiejętność słuchania, chęć niesienia pomocy, potrafię wyjść do świata i ludzi. Wychodzę z izolacji jako kobieta trochę dojrzalsza. Postrzegam siebie w jasnych barwach, nie żyję wspomnieniami, bólami. Pogodziłam się i zaakceptowałam”. Inna dodaje: „patrzę realnie na świat. Nie uciekam od ludzi, nie odkładam prac na później. Nie czuję smutku”. Można byłoby zatem mieć nadzieję, że tym razem terapia alkoholowa i proces wychodzenia $z$ bezdomności będą skuteczne, gdyby nie fakt, iż taki schemat przez wiele z nich był już przerabiany i niestety wcześniej lub później jako alkoholiczki kończyły na ulicy. Człowiek uzależniony niestety do końca życia musi radzić sobie z tym problemem, jednak, jak mówi jedna z rozmówczyń, aby zwiększyć swoje szanse, należy „nie ukrywać się, żyć w prawdzie i rozmawiać”.

\section{Wnioski}

Proces wychodzenia z bezdomności, zwłaszcza osób uzależnionych od alkoholu, jest niezwykle trudnym i złożonym zjawiskiem. Obarczony wieloma współzależnościami, wymaga starań nie tylko osób pomagających, ale przede wszystkim samych dotkniętych tymi patologiami. Jak wynika z przeprowadzonych badań, w przypadku wielu bezdomnych trudno liczyć na pomoc ze strony ich środowiska rodzinnego, a często stanowi ono niestety dodatkowy czynnik ryzyka (np. alkoholizm, przemoc). Niemniej jednak tam, gdzie powrót czy chociażby zbliżenie się jest możliwe, należy bezzwłocznie podjąć działania wzmacniające więzi rodzinne, bo to one są jednymi z najistotniejszych czynników chroniących. Ponowna akceptacja własnego środowiska i przebaczenie ze strony najbliższych dla badanych kobiet stanowiły bowiem moment przełomowy w procesie wychodzenia $\mathrm{z}$ bezdomności.

Wszystkie badane zdają sobie również sprawę z faktu, że muszą od nowa nauczyć się nawiązywania i podtrzymywania kontaktów, umiejętności rozwiązywania konfliktów, a przede wszystkim chęci mówienia o sobie z innymi ludźmi. Wydaje się bowiem, że jednymi z najtrudniejszych do przepracowania konsekwencji alkoholizmu i bezdomności są świadomość permanentnego odrzucenia i konieczność hermetycznego zamknięcia się w swoim świecie. Ponowne 
odzyskanie poczucia godności oraz codzienne budowanie poczucia własnej wartości są szansą wyjścia z błędnego koła problemów.

\section{Bibliografia}

Przymeński A., Aktualny stan problemu bezdomności w Polsce. Aspekt polityczno-społeczny, [w:] Oblicza bezdomności. Materiały pokonferencjyjne, red. M. Dębski, K. Stachura, Gdańsk 2008, s. 17-37.

Baranowski B., Ludzie gościńca w XVII-XVIII w., Łódź 1996.

Ustawa o Pomocy Społecznej z dnia 12 marca 2004 r., Dz.U. nr 64, poz. 593, art. 6, pkt. 8.

Jaroszewska E., Bezdomni jako zbiorowość wykluczona społecznie, [w:] Ubóstwo i wykluczenie społeczne-perspektywa poznawcza, red. R. Szarfenberg, C. Żołędowski, M. Teiss, Warszawa 2010, s. 278-294.

Jaździkowski M., Syndrom bezdomności, http://www.bratalbert.org/files/brat_albert/pdf/ marek_jazdzikowski_syndrom_bezdomnosci.pdf (dostęp: 15.04.2014).

Moczuk E., Bezdomność jako problem społeczny w opiniach osób bezdomnych, [w:] Poczucie nieegalitarności, ubóstwo, bezdomność a zjawiska patologii społecznej w aktualnej rzeczywistości kraju, red. T. SołtysiaK, Włocławek 1999, s. 231-246.

Woronowicz B. T., Bez tajemnic o uzależnieniach $i$ ich leczeniu, Warszawa 2001. 
4. Uniwersytet Papieski 